\title{
As Umbandas no Cordel
}

\section{Umbandas in cordel Literature}

Lourival Andrade Junior*

Resumo: As diversas maneiras de se praticar a Umbanda no Brasil aparecem nos cordéis brasileiros daa mais variadas formas. De forma geral, os cordelistas não conhecem a religião umbandista por dentro, já que em sua maioria são católicos, utilizando assim conceitos e preconceitos já absolutamente aceitos pelo senso comum. Neste sentido, procuramos entender a partir do universo destes cordelistas como as Umbandas são entendidas por estes poetas e como este gênero literário contribuiu para a construção de suas imagens, sobretudo de suas entidades espirituais e dos Orixás.

Palavras-chave: Umbandas; cordel; entidades espirituais; orixás

* Professor Adjunto IV e Chefe do Departamento de História na Universidade Federal do Rio Grande do Norte (UFRN), campus Caicó, Brasil E-mail: lourivalandradejr@yahoo.com.br 


\begin{abstract}
Different ways of practicing Umbanda in Brazil have been recorded in Brazilian cordel poetry in several diverse forms. In general, cordelistas have no personal and direct knowledge about the Umbanda religion itself, given that most of them are Catholic; they, therefore, appropriate concepts and preconcepts widely accepted by common sense. In this sense, we work towards understanding, from cordelistas' perspective and universe, how Umbandas are understood by them, poets, and how this literary genre contributed to the crystallization of Umbandas' image, especially about their spiritual entities and Orixas.
\end{abstract}

Keywords: Umbandas; cordel; spiritual entities; orixás

O cordel é um gênero literário genuinamente brasileiro, mais especificamente, nordestino e nascido no sertão paraibano. Homens sertanejos estabeleceram as normas do que hoje consideramos cordel, entre eles: Leandro Gomes de Barros (Pombal/PB), Silvino Pirauá de Lima (Patos/PB), Francisco das Chagas Batista (Teixeira/PB) e João Martins de Athayde (Ingá/PB). É indiscutível que estes homens ouviam as cantorias de repentistas e travadores que enchiam de poesia o sertão nordestino, e muitas destas cantorias foram levadas para o cordel, ou seja, uma intensa relação entre o oral e o escrito. Isso não quer dizer que o cordel ainda guarde as características estilísticas das cantorias (na maioria das vezes em quadras), mas com o o passar do tempo tornou-se um gênero literário bastante rígido, em que as sextilhas, setilhas, oitavas e décimas precisam seguir regras muito precisas para serem consideradas cordel. É evidente que a musicalidade está presente na métrica e nas rimas do cordel e isso faz com que ouvir esta poesia também marque sua trajetória histórica.

Mesmo o cordel tendo nascido no sertão, as migrações para os grandes centros do país, no nordeste e nas demais regiões, sobretudo após a grande seca de 1877 , fez com que grandes cordelistas levassem sua arte para estas cidades e a partir daí o cordel deixou de ser apenas consumido no nordeste brasileiro e se tornou uma leitura quase que obrigatória para migrantes em São Paulo, Rio de Janeiro, Recife, Salvador, Belém, entre outros grandes centros urbanos. O mercado cordeliano se ampliou consideravelmente com a ida de João Martins de Athayde para Recife e de lá estabeleceu uma rede de comércio que vendeu milhões de exemplares de centenas de títulos. É importante atentar para a questão do cordel estar umbilicalmente ligado a uma origem sertaneja, mas um desenvolvimento a partir da cidade, do urbano. Muitos outros cordelistas se tornaram editores, podemos citar Rodolfo Coelho Cavalcante (Salvador/BA), José Bernardo da Silva (Juazeiro do Norte/CE), entre muitos outros. O cordel não mais trataria de temas sertanejos, mas ampliaria suas temáticas, já que o entorno dos poetas influenciaria sua produção. Estar nas cidades era também um desafio para eles e para os seus leitores. O cordel passaria a cumprir uma 
de suas função básicas, educar, já que por meio de suas pedagogias ensinou muitas gerações a olhar o mundo por seu filtro. Os cordelistas fabricaram, aqui me apropriando do conceito de Durval Muniz de Albuquerque Junior ${ }^{1}$, os seus sertões e teriam que também fabricar as suas cidades, para aqueles que lá estavam e para aqueles que ficaram para trás.

Não nos parece difícil compreender que o cordel estabeleceu marcos históricos para o sertão nordestino, fazendo escolhas do que deveria ser publicado ou não. Esta escolha recaia sobre os cordelistas, sempre muito respeitados, desde a segunda metade do século XIX, período de seu nascimento como gênero, já que era por meio de seus folhetos que as notícias se tornavam verdades. O cordel era o jornal do sertanejo, jornal este inquestionável. Ou seja, os cordelistas ao fazerem suas escolhas também o faziam levando em conta seus leitores e aquilo que eles consideravam relevantes e vendáveis. Não temos dúvida que personagens forjados no nordeste se tornaram nacionais por conta das páginas de folhetos dedicados a eles, aqui podemos citar Padre Cícero e Lampião. São centenas de títulos que até hoje utilizam estas personagens para narrar eventos diversos. Sua coragem, independentemente de suas atrocidades, são elevadas ao cânones da glória. O cordel, como já dissemos, vendidos em todas as partes do país e para milhares de brasileiros, norteavam os olhares e falas de seus leitores no tocante a estas personagens e aos eventos que realmente participaram ou que ficcionalmente eram construídos.

Nos últimos dois anos percorri vinte e sete acervos de cordéis, os maiores e mais representativos do Brasil, em quinze cidade e oito estados. Entrei em contato com mais de noventa e cinco mil folhetos, catalogando títulos que tratassem das religiões afro-brasileiras e de temáticas ligadas a outras linhas de pesquisa que desenvolvo no campo das religiões e religiosidades. Tendo a Umbanda como temática principal encontrei apenas seis cordéis, o que demostra ainda um assunto pouco discutido no universo cordeliano.

Quero logo chegar no tema deste artigo, as Umbandas no cordel, mas é preciso adentrar um pouco no campo das religiões e religiosidades, e é aí que a produção cordelista ganha força ao longo de sua história. Os catolicismos em suas variadas possibilidades no país aparecem contundentemente nas obras de autores cordelistas. Personagens do mundo católico aparecem reiteradamente em folhetos tanto produzidos no sertão como nos grandes centros, posso destacar: os Papas (sobretudo João Paulo II), Padre Cícero, Frei Damião, Antônio Conselheiro, santos e santas, milagreiros de cemitério e de rua. Os cordelistas nasceram e se criaram num espaço tomado pelo catolicismo e sua produção artística vai reforçar estes discursos, fazendo com que a produção cordelista, no tocante a religião e religiosidade, esteja intimamente ligada a este catolicismo. Lembrar que além dos próprios autores, os leitores/ouvintes, ou seja, os consumidores, também eram católicos e o cordelista escrevia para quem vai lê-lo, reafirmando convicções e ideologias. Cria-se um círculo de 
produção e consumo que não se conflitam, muito pelo contrário, se ratificam.

No nordeste e sobretudo no sertão, e depois também nos grandes centros urbanos a produção cordeliana estava intimamente relacionada ao catolicismo oficial e não oficial, que tendiam ao conservadorismo. Assim era necessário separar o que era aceito pelo catolicismo e o que era condenado, como a "macumba", o "catimbó", o feitiço". Estes termos aparecem desde os primeiros cordéis do século XIX e vão ganhar força no XX. Utilizados como forma de desqualificar estas práticas, colocam no mesmo caudal, feiticeiras e bruxas medievais, adivinhos e videntes, inclusive São Jorge que é chamado de catimbozeiro pelo Imperador Diocleciano quando não morre em seus primeiros martírios, como descreve Gonçalo Ferreira da Silva em seu folheto "São Jorge o santo guerreiro", publicado pela Academia Brasileira de Literatura de Cordel, no Rio de Janeiro em agosto de 2006. Rezas e benzeduras não podiam ser confundidas com estas práticas vistas como abomináveis, rústicas e perigosas. Tudo se mistura ao gosto do poeta e de seus leitores. O senso comum é a lógica do cordelista, "para que mudar aquilo que todo mundo já conhece e reconhece" como afirmou o poeta Rodolfo Coelho Cavalcante. Sem dúvida, muitos, se não a maioria, reforçam os conceitos de raça, negro com inferior, mulher tendo que se comportar como "bela, recatada e do lar", entre outros preconceitos que hoje abominamos, ou pelo menos deveríamos abominar. O cordel é uma lente de aumento da realidade, expondo suas fraturas e preconceitos. Ao cordelista não cabia, no passado e em muitos casos no presente, questionar o que seus leitores acreditavam, fazendo com que possamos entender por meio de seus versos e estrofes o pensamento mais geral da população brasileira. $\mathrm{O}$ cordel é um documento histórico, antropológico e sociológico dos mais vibrantes, já que escancara as mazelas que normalmente são escondidas das grandes mídias ou minimizadas por outros gêneros literários. $\mathrm{O}$ "politicamente correto" no cordel tem pouco espaço já que se forja nas vivências e falas de seus poetas e que estão no mesmo espaço social e cultural de seus leitores. Não nos cabe a censura, mas saber utilizar estas fontes como material privilegiado de pesquisa.

No caso da Umbanda é importante lembrar que ela se constitui como religião somente no início do século $\mathrm{XX}$, mais precisamente em 15 de novembro de 1908, com Zélio Fernandino de Moraes e seu Caboclo das Sete Encruzilhadas. A Umbanda não seria mais a macumba carioca nem o candomblé baiano. Ela teria suas próprias práticas e rituais. Sendo uma religião brasileira que possui elementos africanos, católicos, kardecistas e da pajelança, passou a buscar uma autonomia e reconhecimento social, cultural e político. De qualquer forma, a própria dinâmica da Umbanda criada por Zélio, fez com que surgissem com o passar das décadas, o que podemos chamar de Umbandas, tendo fundamentos comuns, mas rituais específicos: Umbanda Branca, Umbanda Pura, Umbanda Popular, Umbanda Tradicional, Umbanda Esotérica ou Iniciática, Umbanda Trançada ou Mista, Omolocô, Umbanda de 
Caboclo, Umbanda de Jurema, Umbandaime, Umbanda Eclética, Umbanda Sagrada ou Natural, Umbanda Cristã, Umbandomblé e Umbanda de Almas e Angola. Além disso, como a Umbanda em todas as suas variações é uma religião inclusiva, novas entidades começaram a pertencer ao panteão umbandista, além dos já tradicionais caboclos, pretos-velhos, crianças, exus e pomba-giras. Podemos citar a inclusão de: boiadeiros, vaqueiros, cangaceiros, povos do oriente, malandros, marinheiros, ciganos, entre outros. Somente encontramos folhetos falando diretamente da Umbanda a partir da década de 70 do século passado, e poucos, justamente num momento de crescimento da Umbanda, em plena Ditadura Militar. Estes seis cordéis encontrados tratam com respeito a Umbanda, diferente do que ocorria com outas religiões, inclusive a protestante que foi durante muitas décadas duramente criticada nos cordéis, chamada de "nova seita", "igreja do diabo" e por aí vai. Também encontrei muitos cordéis que tratavam de entidades de Umbanda e que também analisarei alguns deles. Vale também destacar que em muitos outros cordéis aparecem no corpo de seus textos termos relacionados com a Umbanda, mas para este artigo decidi por escolher apenas aqueles que em seus títulos aparecem explicitamente o termo "Umbanda".

Assim, reforçamos o que dissemos anteriormente que o cordel se modificou com o tempo em suas temáticas, não se fossilizou, como era o desejo dos folcloristas e estudiosos da cultura popular do início do século XX, que viam estas novas temáticas como degenerações, já que abandonavam temáticas sertanejas, rurais e passaram a falar também de temáticas urbanas. A Umbanda é essencialmente urbana. Vamos aos cordéis.

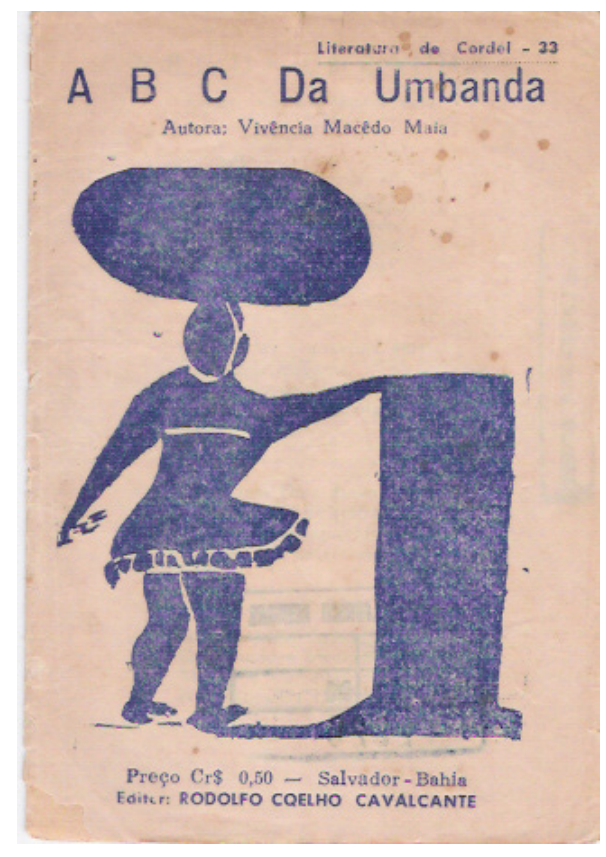


Imagem 1: Capa do cordel "ABC da Umbanda" de Vicência Macêdo Maia, 1972. (Acervo: Programa de Pesquisa em Literatura Popular - UFPB - João Pessoa/PB)

O primeiro é "ABC da Umbanda" de Vicência Macedo Maia publicado em Salvador em 1972 pelo editor Rodolfo Coelho Cavalcante, este o maior divulgador do cordel em todos os tempos, organizando congressos, lutando pelo reconhecimento do direito autoral, fundando associações e federações, além de ser um profícuo poeta com mais de 1.000 títulos publicados. O interessante é também a trajetória religiosa de Rodolfo. Era católico, se tornou protestante e por fim kardecista. Não diferente de outros cordelistas, via nas práticas de feitiçaria, macumba e catimbó algo que renegava a verdadeira fé. Publicou alguns títulos falando sobre estes assuntos, alguns de forma mais contundente na defesa do controle destas práticas, outras nem tanto, beirando a generosidade. Este folheto "ABC da Umbanda" segue um modelo clássico dos cordéis os $\mathrm{ABCs}$, em que a primeira letra de cada estrofe segue a sequência do alfabeto de A a Z. Em relação ao tema, percebe-se que a autora, isto algo incomum no mundo cordeliano, usa de termos genéricos sobre a religião sem se aprofundar no que realmente são seus fundamentos. $\mathrm{O}$ historiador norte americano Mark Curran, uma das maiores autoridades no estudo do cordel, em seu livro "Retratos do Brasil em Cordel"2 cita este folheto e informa que ele possa ter sido encomendado, como uma forma de passar uma imagem positiva da religião umbandista. Talvez Curran esteja correto por conta de um detalhe, o cordel é em quadra, estilo que Rodolfo Coelho Cavalcante considerava menor ou até mesmo não o considerava cordel. Neste sentido, pode ser que Rodolfo tenha sido remunerado para publicar desta forma, o que no caso dele, homem também de negócios, fica fácil compreender. A autora utiliza termos que são muito mais próximos do kardecismo (religião do editor) do que da própria Umbanda: Doutrina, Mentores, seara. Também faz questão de diferenciar Umbanda de Espiritismo, sendo a última "ciência" e a Umbanda "mediunidade". Aqui aparece o embate por reconhecimento que tanto o espiritismo kardecista lutava estabelecendo diferenças entre suas práticas e as outras religiões mediúnicas. Também fica evidente que a escrita da autora também está marcada pela descrição não de entidades da Umbanda, mas sim dos Orixás, muito mais comuns em Salvador na década de setenta do século passado em seus candomblés. Ela cita: OXALÁ, OGUM, OXOSSE e Yansã, esta segundo Vicência: "Yansan-Deusa Divina/Senhora do verde mar/ Em tua fonte cristalina/Quero meu corpo banhar" (p. 6), mostrando, que na Bahia, Yansã ocupava o espaço sagrado de Iemanjá, o mar, pelo menos naquele momento e segundo as pesquisas da autora. Vale aqui também observar com mais atenção a capa do folheto, que pouco remete a Umbanda. Utilizando o conceito de análise "verbovisual" de Alberto Roiphe do livro "Forrobodó na linguagem do sertão: leitura verbovisual de folhetos de cordel", percebemos que o editor não estava preocupado em demonstrar na capa uma leitura mais 
enfática e coerente sobre a Umbanda. A xilogravura não possui autoria e mostra uma mulher, aparentemente negra e sem rosto definido, com um vestido rodado e curto, segurando algo que se assemelha a um tronco de árvore cortado, mas que pode ser um atabaque desproporcional. Chama a atenção o volume que está sobre sua cabeça, que em nada remete a algum elemento da liturgia e ritual umbandista, nem tão pouco ao que aparece no texto. Podemos aqui especular que esta xilo já fazia parte do acervo do editor e este aproveitou para utilizar neste folheto. Era prática de Rodolfo contratar xilogravuristas que apresentavam a ele diversas versões para o mesmo folheto. Observando com atenção, a imagem se parece com uma personagem recorrente em cordéis de autores diversos, a "Negra da Trouxa", que é sempre descrita como feiticeira, bruxa, catimbozeira, macumbeira, conceitos desqualificados no mundo cordeliano. Vale lembrar que o próprio Rodolfo publicou um folheto com esta temática: “ $A$ Negra da Trouxa Misteriosa Procurando Tu". Neste sentido, parece que o editor, mesmo que tenha sido pago para publicá-lo não estava muito confortável com sua veiculação, mostrando um certo desleixo para com o cordel e sua temática.

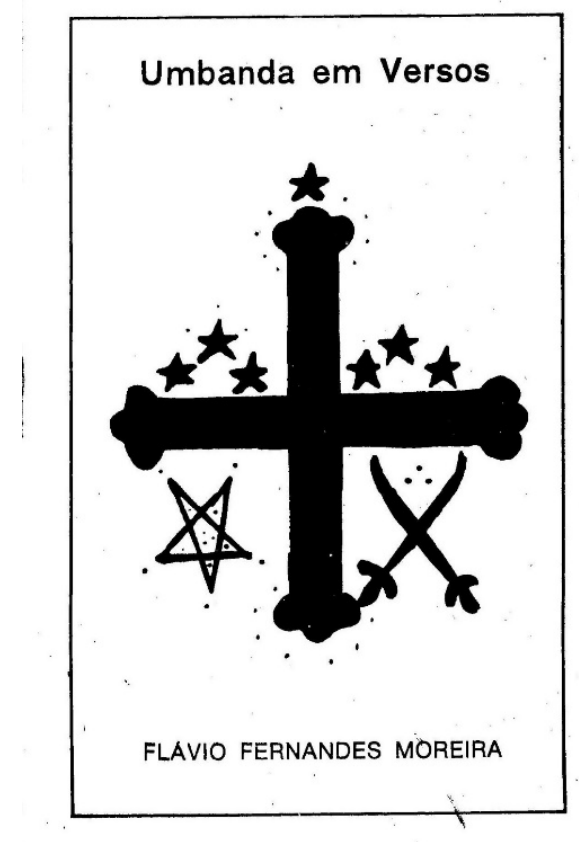

Imagem 2: Capa do cordel "Umbanda em Versos" de Flávio Fernandes Moreira, 1978. (Acervo: Biblioteca de Obras Raras Átila Almeida - UEPB Campina Grande/PB)

No cordel em sextilha "Umbanda em versos" de Flávio Fernandes Moreira publicado em 1978 pelo Governo do Estado do Rio de Janeiro, Secretaria de Estado de Educação e Cultura, Departamento de Cultura e 
Instituto Estadual do Livro, ou seja, um folheto reconhecido pelas instituições do estado carioca. Flávio Fernandes Moreira era motorista de ônibus em Duque de Caxias/RJ e escreveu cordéis com temáticas de seu cotidiano, como por exemplo "O drama do motorista", inclusive seus passageiros eram os maiores compradores de seus folhetos. E porque escrever sobre a Umbanda? Desde os 15 anos era palhaço nas folias de reis, e este folguedo fluminense era muito ligado a Oxossi, o caçador, os caboclos, São Sebastião, tudo misturado, como bem descreveu Marlyse Meyer em seu livro "Caminhos do imaginário no Brasil"4. Muitas destas folias também estavam ligadas aos terreiros de Umbanda e em muitos casos passavam em seu caminho por terreiros e reverenciavam o congá, o altar umbandista. Daí vem a inspiração do autor. A capa, sem autoria, é bastante representativa. Observamos estrelas comuns em pontos riscados de caboclos e pretos-velhos, a cruz da trindade ou cruz em trevo, representando a Trindade (a Umbanda é uma religião cristã) e duas espadas cruzadas que aparecem em pontos riscados de entidades que trabalham da linha de Ogum, o orixá guerreiro. O folheto em dezessete páginas apresenta a Umbanda e todas as suas qualidades como espaço da fé e da harmonia entre santos católicos, entidades e orixás.

O autor demonstra conhecer o universo umbandista, pois utiliza termos e conceitos utilizados nesta religião. Seu cordel é mais objetivo e não genérico como o anterior. Sabemos que um umbandista é pertencente a uma casa, a um terreiro e dele carrega a visão da Umbanda deste espaço, de seus pais e mães de santo e das entidades espirituais que neles atuam. O autor nos dá a impressão de ser membro de uma casa de Umbanda, sem citá-la: "Leitores então ouçam bem/os versos que vou citar/espero que meus irmãos/hão de ver e me apoiar/ só mesmo quem não tem fé/é que pode duvidar" (p. 2) e mais a frente, afirma "não vamos medir esforços/para ajudar um irmão/vai subir mais um degrau/no caminho da salvação/assim nosso próprio guia/ganha mais um galardão."(p. 12). Também aproveita o cordel para dar conselhos aos umbandistas e aos consulentes, dizendo: "Aviso para quem não sabe/que procurem entender/que é bom tratar dos santos/para na vida vencer/queira bem aos Orixás/que o bem vais receber" (p. 12) e ainda "aviso aos consulentes/que preste bem atenção/no lugar aonde for/vê se há concentração/no meio dos bons espíritas/pode estar um charlatão" (p.14). Fica claro a preocupação do autor em separar o que ele considera a boa e a má prática mediúnica, e nos informa que na Umbanda também haviam os mistificadores, enganadores, os charlatões que o próprio movimento Umbandista através da federações tentava coibir.

Flávio Fernandes também apresenta as Sete Linhas de Umbanda, que sabemos são diferentes de terreiro para terreiro. Na sua compreensão, as sete linhas estão diretamente ligadas aos santos católicos, tanto que a primeira delas é só comporta destes santos, que ele não nomeia. As outras seis linhas são: Iemanjá (Virgem Maria), Oriente (São João Batista), Oxosse (São Sebastião), 
Ogum (São Jorge), Xangô (São Jerônimo) e Preto Velho. Com exceção deste último, ao falar sobre suas funções, diz que são grandes quebradores de feitiços, magia e demandas dos quimbandeiros. É interessante notar que o autor vê a magia negativamente, o que é estranho quando pensamos que a Umbanda é uma religião que utiliza em seus rituais a magia como forma de resolver problemas imediatos tanto espirituais quanto materiais de seus consulentes e médiuns.

Além destas sete linhas, ainda apresenta e descreve os poderes de mais alguns Orixás: Nanã Buruque, Iansã, Oxum e as crianças (Ibejadas) que ele associa a São Cosme e Damião.

Outro tema levantado pelo autor é a separação que ele faz entre Umbanda e Quimbanda. Sendo a primeira a praticante do bem e a segunda do mal (mas que também pode fazer o bem). Na década de setenta, período da publicação do folheto, os intelectuais de Umbanda e as autoridades públicas, buscavam dar um caráter mais aprazível para a Umbanda que crescia, e separála do que se consideravam uma prática primitiva e não cristã era um dos grandes objetivos. $\mathrm{O}$ autor fala que a Quimbanda tem um maioral, um chefe que segundo ele é Lucifer e tendo Exu como o espírito mais conhecido deste "lado" da espiritualidade. A partir de nossos estudos sobre a Umbanda e de entrevistar diversos estudiosos do assunto e de sacerdotes de Umbanda, entre eles o estudioso e pai de santo Alexandre Cumino, do Colégio Pena Branca em São Paulo/SP, esta separação já não se aplica, visto que na maioria esmagadora dos terreiros de Umbanda no Brasil, as falanges de caboclos e pretos-velhos, por exemplo, atuam lado a lado com exus e pombagiras. Todos cumprem um papel no ritual umbandista e a falta de uma das colunas pode fazer ruir o prédio da espiritualidade. O autor inclusive demonstra que conhece pontos de Exu, tanto que em uma das estrofes informa que "Sem Exu não se faz nada" (p. 10), frase comum em vários pontos de Exus.

Esta ideia de legitimação também fica clara quando o autor conclama os umbandista a apoiar Atila Nunes, que havia sido deputado estadual de 1960-1962, sendo ele um sacerdote de Umbanda conhecido no Rio de Janeiro e radialista que utilizava este espaço para divulgar a religião e acabar com o preconceito.

$\mathrm{O}$ autor ao concluir o folheto, aproveita para se desculpar caso tenha cometido algum equívoco durante sua narrativa, dizendo "fica aqui o meu pedido/leia sempre este folheto/aquele que ler correto/veja lá se tem defeito/ inspiração vem de Deus/o poeta dá só um jeito" (p. 17). 


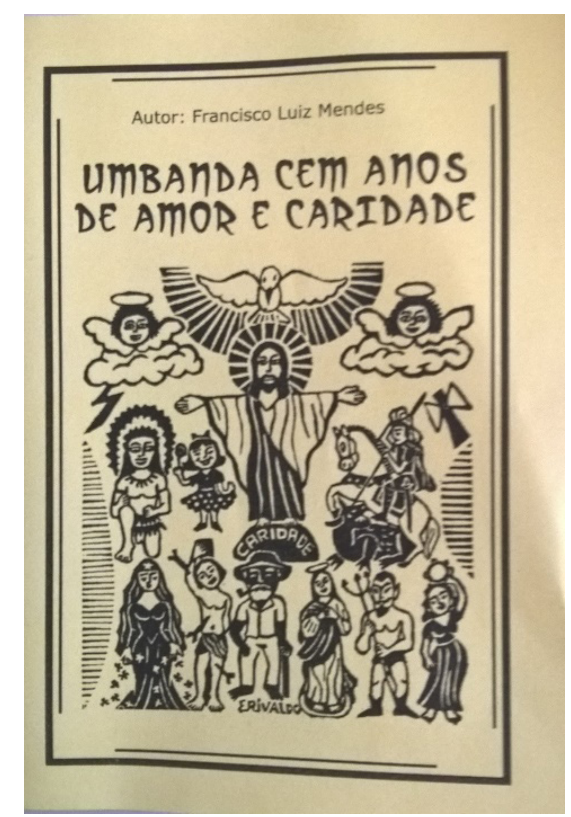

Imagem 3: Capa do Cordel "Umbanda Cem Anos de Amor e Caridade" de Francisco Luiz Mendes, 2008. (Acervo pessoal)

No cordel "Umbanda Cem Anos de Amor e Caridade" de Francisco Luiz Mendes datado de 2008 e publicado pela Editora Coqueiro com 11 páginas, a história da Umbanda é apresentada detalhadamente. $\mathrm{O}$ autor é bancário aposentado e graduado em Letras pela Universidade Metodista de São Paulo, natural do interior da Paraíba e atualmente residindo em São Caetano do Sul/ SP. Mais uma mudança na produção cordeliana, não somente homens simples, da roça e semi-analfabetos continuaram a produzir cordel. $\mathrm{O}$ mundo urbano misturou tudo e este rural idílico ficou no passado ou no saudosismo dos folcloristas.

Um detalhe muito importante deste folheto é a capa assinada por Erivaldo, um dos mais importantes xilogravuristas da atualidade que vive no Rio de Janeiro. A capa mostra de forma inequívoca toda a hibridação da Umbanda e suas conexões. Temos: a pomba do Espírito Santo, Jesus Cristo de braços abertos (não é comum encontrar o cristo crucificado nos terreiros, a imagem mais presente é ele ressuscitado), anjos em suas nuvens, São Jorge, Nossa Senhora da Conceição, São Sebastião, um caboclo (índio), criança (Ibejada), Iemanjá, Preto-velho, cigana, Exu e um oxé (machado de Xangô). Abaixo de uma das nuvens parece ser um raio, o que simbolizaria Insã. Ao longo do cordel o autor vai fazendo estas relações, entre santos católicos, Orixás e entidades de Umbanda.

Este cordel pode ser entendido como fazendo parte das comemorações do centenário da Umbanda e no ano de sua publicação (2008) tivemos vários 
livros, congressos, documentários que tinham a Umbanda como tema. O autor discorre de como a Umbanda é desprovida de preconceitos, que para ela podem acorrer todo e qualquer pessoa, nas palavras do autor: "Menino, moça e rapaz/Negro, branco amarelo/Aleijado, feio, belo/Rico, pobre, tanto faz!" (p. 1). Esta mesma postura inclusiva é destacada na composição do panteão que ele descreve (ele fala das sete linhas, mas não as expecifica). Fala sim de entidades que foram incorporadas pela Umbanda (baianos, boiadeiros, ciganos e marinheiros) e das tradicionais (caboclos, pretos velhos, pombagiras e erês). Ao longo do texto vai apresentando os Orixás que atuam na religião: Obá, Oxum, Iemanjá, Ogum, Oxóssi, Xangô, Iansã, Oxalá. Também liga alguns destes orixás aos santos católicos: São Jorge, São Sebastião, São Lázaro, Nossa Senhora da Conceição, São João Batista, Cosme e Damião. Outro detalhe que chama a atenção é que o autor cita Santa Sara Kali, como fazendo parte deste panteão. Isto não é comum. Esta santa é a santa de devoção de ciganos e ciganas espalhados por todo o mundo, inclusive seu dia é comemorado em 25 de maio de todos os anos em várias partes, inclusive no Brasil na Praia de Ipanema no Rio de Janeiro. Fica claro que o autor pesquisou a história da Umbanda para escrever este cordel: historia a sua fundação com Zélio Fernandino de Moraes e o Caboclo das Sete Encruzilhadas, relata as perseguições sofridas no passado e no presente, mostra a importância dos atabaques, cambones, defumações, cantos, da linha de esquerda, de todas as falanges e de Zé Pelintra (inclusive este autor publicou um outro cordel com o título "Salve o mestre Zé Pelintra", que veremos mais a frente).

Um virtude que recorrentemente aparece ligada a Umbanda é a caridade. Neste último folheto aparece já no título (Amor e caridade) e mais quatro vezes no interior do cordel. No de Vicência ( $\mathrm{ABC}$ da Umbanda), também quatro vezes e no de Flávio duas vezes. A ideia de caridade dá a Umbanda uma legitimidade no campo social e mostra que é uma religião dedicada aos outros, que sua prática mágica serve para o mundo exterior e não somente para seus adeptos. A caridade neste caso tanto é no plano material como espiritual. A caridade como forma de alcançar reconhecimento para sua prática religiosa. Aos poucos a Umbanda vai ganhando espaço também no cordel. 


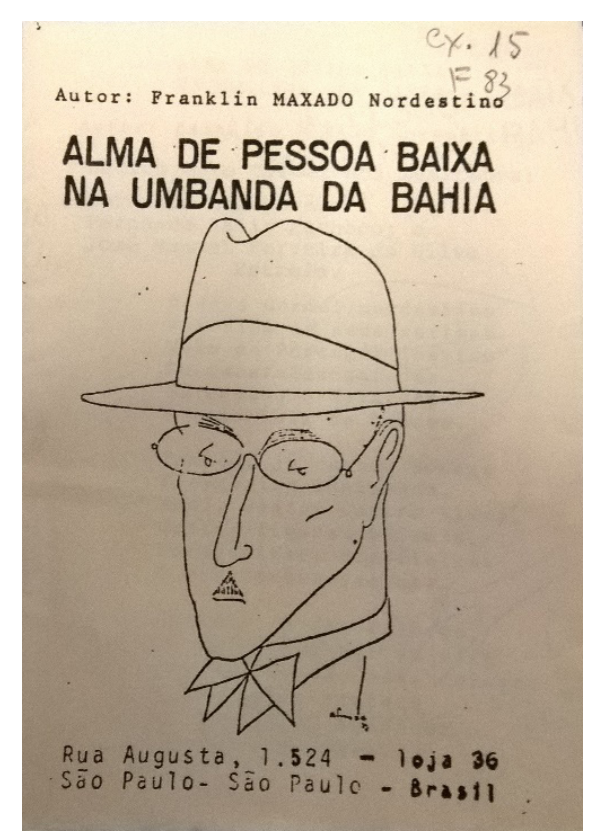

Imagem 4. Capa do cordel "Alma de Pessoa baixa na Umbanda da Bahia" de Franklin Maxado Nordestino, 1985. (Acervo do Setor de Documentação Baiana da Biblioteca Pública do Estado da Bahia - Salvador/BA)

Neste cordel de Franklin Maxado Nordestino (Franklin Serqueira Machado), publicado em Salvador no mês de novembro de 1985, o autor nascido em 15 de março de 1943 em Feira de Santana/BA, nos coloca diante de uma personagem bastante conhecida da literatura universal que é o poeta português Fernando Pessoa. O cordelista Franklin Maxado Nordestino, muito jovem foi morar no Rio de Janeiro e depois em São Paulo, sendo formado em jornalismo possui mais de cem títulos publicados e muitos tratam de temáticas ligados as religiões afro-brasileiras. Ao entrevista-lo em Feira de Santana/BA (08/10/2016), me relatou que na infância frequentava terreiros de Candomblé e Umbanda com sua mãe e sua tia e de forma alguma tem qualquer preconceito em relação a estas religiões, inclusive afirmou que é fundamental conhecer e entender já que elas fazem parte da constituição religiosa do Brasil e em especial da Bahia.

Diferente dos outros cordéis analisados até agora, a capa deste não é original. $\mathrm{O}$ autor utiliza o desenho consagrado do pintor, escritor e desenhista José Sobral de Almada Negreiros, um dos artistas mais consagrados do modernismo português.

Mesmo no título aparecendo que Fernando Pessoa "baixou" em uma sessão de Umbanda, o autor não apresenta elementos suficientes para identificar se realmente era Umbanda ou se seria uma sessão kardecista. De qualquer forma isso demostra como a Umbanda aparece de diversas maneiras para aqueles que escrevem ou poetizam sobre ela. O poeta informa que "tinha 
ido a um centro/Espírita para ouvir/doutrinação para as almas/e o Além discutir/acompanhado do amigo/Escritor Luiz Ademir" (p. 2). No silêncio da concentração dos médiuns surge uma voz de português que se apresenta como Fernando Pessoa e todos seus heterônimos, incorporado em um dos membros da sessão. É interessante apontar que o autor diz que isto estava acontecendo porque Fernando Pessoa era também "perturbado" em vida e por isso "está no inferno" (p. 2) e "foi como alma penada/que me baixou na Bahia" (p. 2). Ao longo das 8 páginas e mais a quarta capa, o autor vai citando várias citações de textos de Fernando Pessoa, mostrando sua personalidade diversa, inclusive se mostrando fatalista ao decantar o "sebastianismo" (p. 4).

A única indicação clara da incorporação aparece quanto o autor, ao final do folheto, informa: "seu aparelho tremeu/e o espírito subiu/foi assim tão de repente/como chegou já partiu" (p. 8). Neste folheto o que temos é uma personagem histórica que para se comunicar faz uso de uma religião mediúnica, que não se caracteriza como Umbanda, mas sim com o kardecismo. Fernando Pessoa não se enquadra como entidade espiritual umbandista, nem faz parte de seu panteão. A licença poética do autor coloca o leitor e ele mesmo em sintonia com o poeta lusitano por meio da incorporação mediúnica, utilizada unicamente como possibilidade de conexão e nada além disso.

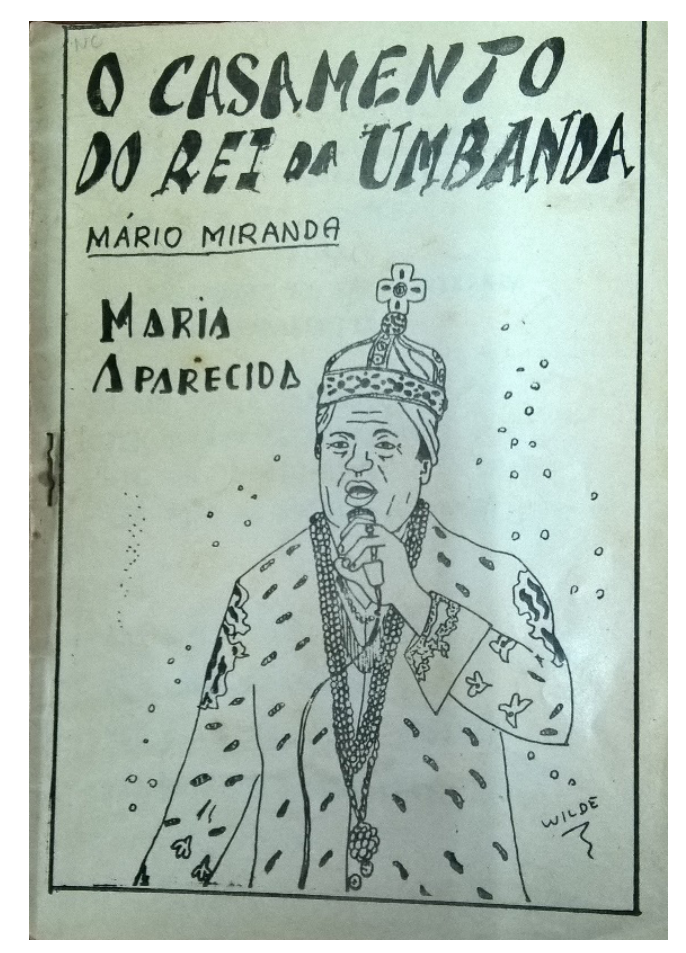

Imagem 5: Capa do cordel "O casamento do rei da Umbanda Mário Miranda Maria Aparecida” de Zoé Farias, s/d. (Acervo: Fundação Casa de Rui Barbosa - Rio de 
Janeiro/RJ)

O cordel "O casamento do Rei da Umbanda Mário Miranda Maria Aparecida" de Zoé Farias nos deixa apenas pistas do local de sua publicação e de sua datação. Em sua capa temos o desenho de Wilde representando Mario Miranda com a coroa do Maracatu Nação Cambinda Estrela em que foi folião durante muitas décadas. Além de babalorixá, Mario Miranda, que preferia ser chamado de Maria Aparecida, era figura conhecida no carnaval de Recife, confeccionando suas fantasias e pulando todos os dias da folia. A capa dialoga muito mais com Mario Miranda como carnavalesco do que como pai de santo. A análise verbovisual é um elemento determinante para que se possa observar a linguagem do autor e colocar o folheto no tempo e no espaço.

A narrativa do folheto se atem a descrever os preparativos do casamento de Mario Miranda com Diva, que segundo o autor colocou a personagem principal numa posição de aceitar as imposições da futura esposa, sem questionar. Um dos pedidos era para que Mario deixasse crescer o bigode e que se despedisse de sua Maria Aparecida. É neste contexto que é possível definir o local da publicação do folheto, Recife, cidade que Mario Miranda se tornou pai de santo do candomblé, mais precisamente do Xangô pernambucano, de nação Moçambique. Filho de Oxum, conduziu seu terreiro até a década de oitenta do século passado quando veio a falecer.

Ao informar a lista dos convidados o autor nos dá as pistas para se chegar a uma datação de sua publicação. Entre os convidados, "vem até outro nome famoso/Um político da ARENA/É o prefeito da cidade/O nosso Augusto Lucena" (p.3). Augusto Lucena foi Prefeito do Recife, nomeado por indicação do governador de Pernambuco Eraldo Gueiros Leite, de 1971 a 1975. Outra pista é o convite feito ao Deputado Manoel Gilberto, que além de político era médico e compositor de vários frevos famosos nos carnavais de Recife, entre eles, "Menina de Hoje", “Às cinco da manhã" e "Vai pegar fogo". Sua legislatura foi no início da década de setenta do século passado. Ou seja, este folheto foi escrito e publicado entre os anos de 1971 a 1975 em Recife.

Além destes políticos, o folheto mostra o quanto Mario Miranda era respeitado no Brasil, inclusive com a possibilidade da presença do apresentador Silvio Santos, da sambista Míriam Batucada, de um time de futebol da Europa, da seleção do Haití e teria cobertura da Revista Veja. A hipérbole é uma das características da produção cordeliana.

Também religiosos constavam como convidados, inclusive "tem outro que foi convidado/Que vai calar muito tagarela/É o pároco do Jordão/O querido padre Geraldo Magela" (p. 7). O religioso em questão é Dom Geraldo Magela do Nascimento, atualmente diocesano responsável pela Diocese de Jaboatão dos Guararapes/PE da Igreja Católica Apostólica Brasileira (ICAB). E não poderia deixar de faltar os mais famosos sacerdotes do candomblé naquele momento, Mãe Menininha do Gantois (Salvador/BA) e Pai Edu (Olinda/PE), 
sendo estas duas personalidades as mais conhecidas figuras do Candomblé no Brasil nos anos setenta. Outra personagem muito relevante para a História das religiões afro-brasileiras e que aparece entre os convidados é Carlos Leal Rodrigues, que foi o primeiro presidente da Federação dos Cultos Africanos da Paraíba, fundada em 1966.

Ao final do folheto o autor deixa a última informação, que sem dúvida, para ele qualificaria o casamento de Mario Miranda: "Agora que vou chegando ao fim/Tenho algo a declarar/Quem celebra o casamento/É "Pai Edú" no Palácio de Iemanjá" (p. 8).

O título de "Rei" da Umbanda dado pelo cordelista a Mario Miranda é aleatório e se refere ao que pensa o autor, não encontrando parâmetros legais e religiosos para este título nobiliárquico. A Umbanda não possui uma hierarquia fora do terreiro, fora do espaço sagrado. No caso das federações, os membros da diretoria cumprem apenas papeis burocráticos e políticos, e seguem a estrutura organizacional republicana. Não há Rei ou Rainha na Umbanda, da mesma forma que Mario Miranda era ligado ao Candomblé/Xangô e não a Umbanda como sugere o poeta em seu título.

O cordel de capa cega "Por que se combate a Umbanda?" do itabunense José Roque Moreira Gonçalves, publicado na cidade do Rio de Janeiro em 1986, é o primeiro cordel da Coleção Espiritualista, escrita e editada pelo autor. Este foi para o Rio de Janeiro de 1940 trabalhar como pedreiro e por gostar e pesquisar a cultura popular, passou a escrever em jornais do Rio e das cidades da baixada fluminense e depois de muita insistência começou a publicar seus primeiros cordéis com apoio do Presidente da Associação dos Repentistas e Cordelistas do Brasil (ARCOB) o editor e poeta Expedito F. da Silva.

No transcorrer de seu folheto o autor informa que estudou para poder escrever sobre a Umbanda e mesmo assim encontrou pouco material e considerou confuso os livros sobre o tema. É justamente neste período, décadas de 1980 e 1990, que a Umbanda passou por um período de refluxo e sua produção intelectual era bastante heterogênea e desencontrada, como apontou Alexandre Cumino em seu livro "História da Umbanda: uma religião brasileira"s. Os intelectuais umbandistas publicaram diversos livros a partir de suas convicções e de sua Umbanda, levando esta religião para uma africanização e em outro momento para seu branqueamento. As diversas Umbandas se digladiavam nas páginas dos livros, cada terreiro cultuava seus Orixás e entidades a partir dos conselhos dos pais e mães de santo e seus guias espirituais, sobretudo as entidades donas da cabeça dos sacerdotes e guardiãs das casas/centros/terreiros/choças. Assim a Umbanda se formou, na diversidade de culto e nas especificidades locais.

De qualquer forma, o autor do cordel buscou o igual na diferença, conduzindo o leitor por questões que, segundo ele, afligem toda a humanidade: natureza, Deus, universo, quem somos neste espaço, entre outras. A partir 
destas divagações conclui que só a religião pode responder e que todos os homens e mulheres possuem suas culturas e por conta disso são diferentes, explicando também as diferenças religiosas, e que todos, desta forma, devem ser respeitadas, já que Deus criou o homem, mas não as religiões. Historiciza a intolerância religiosa, informando que já foi maior entre católicos e protestantes, mas que muitos destes imbróglios foram superados, mas que ainda persistia a intolerância para com as religiões "espíritas", sendo a Umbanda uma delas. Como o autor enquadra a Umbanda como espírita, aproveita para questionar o preconceito que os kardecistas tem em relação a ela. Segundo José Roque Moreira Gonçalves, os kardecistas veem a Umbanda como uma prática involuída e que precisa subir muitos degraus para ganhar o status de religião, já que é vista como seita.

Sobre a Umbanda propriamente dita, o cordelista reclama que a maioria dos que a procuram o fazem pela dor e esperam respostas rápidas para suas aflições. Muitos que conseguem se quer tem a coragem de dizer que lá foi conquistado o seu desejo, fazendo com que a Umbanda sempre esteja na periferia. Também descreve pormenorizadamente os poderes do pai de santo, chefe do terreiro. Seus saberes em relação a cura, utilização de ervas e da magia são enaltecidos pelo autor, mesmo considerando que muitos deles são ignorantes e por isso não falam sobre "os segredos" de sua religião, muito mais por não saberem explicar do que por serem segredos efetivamente. Neste item o autor, é bastante contraditório. Em alguns versos reclama desta falta de letramento e expertise dos membros da religião, mas em outro momento compara-os aos discípulos de Jesus, que segundo ele também eram ignorantes e iletrados e que esta simplicidade os faziam maiores que os doutores.

Sem utilizar conceitos como sincretismo ou hibridismo, o autor discorre sobre as influências que a Umbanda passou em sua formação, deste cultos africanos até seitas de outros continentes e regiões, sem aprofundar estas questões.

O seu ponto de vista fica bastante claro ao escrever que "os preconceituosos que atacam/A UMBANDA como religião,/Não conhecem sua essência/Seus fundamentos e razão,/São pessoas desonestas/E cheias de presunção" (p. 16).

Uma das características mais visíveis da Umbanda são suas entidades espirituais, como já citadas anteriormente. Mesmo ao longo destes mais de cem anos, a Umbanda incorporando novas entidades em seu panteão, ainda prevalecem as mais longevas, entre elas os pretos velhos, crianças (erês) e os exus. Notadamente os caboclos são uma marca da Umbanda e se espalharam por outras religiões, fazendo nascer, por exemplo, o Candomblé de Caboclo, em que estas entidades indígenas brasileiras adentraram o universo ritualístico dos tradicionais Orixás africanos. Mas nos cordéis são raramente citados, e quando o são, normalmente estão associados a Oxóssi e não como entidades 
específicas, com excessão do Caboclo das Sete Encruzilhadas, fundador da Umbanda, já citado no cordel "Umbanda Cem anos de amor e caridade". O cordel "Por que se combate a Umbanda?", nos dá a chave para entendermos como algumas destas entidades aparecem nas produções cordelianas, afirmando que "as elevadas ENTIDADES/Dos planos ESPIRITUAIS/Vem com muita humildade/Em todos os cerimoniais,/Onde com o seu grande poder/Fazem coisas sensacionais" (p. 13).

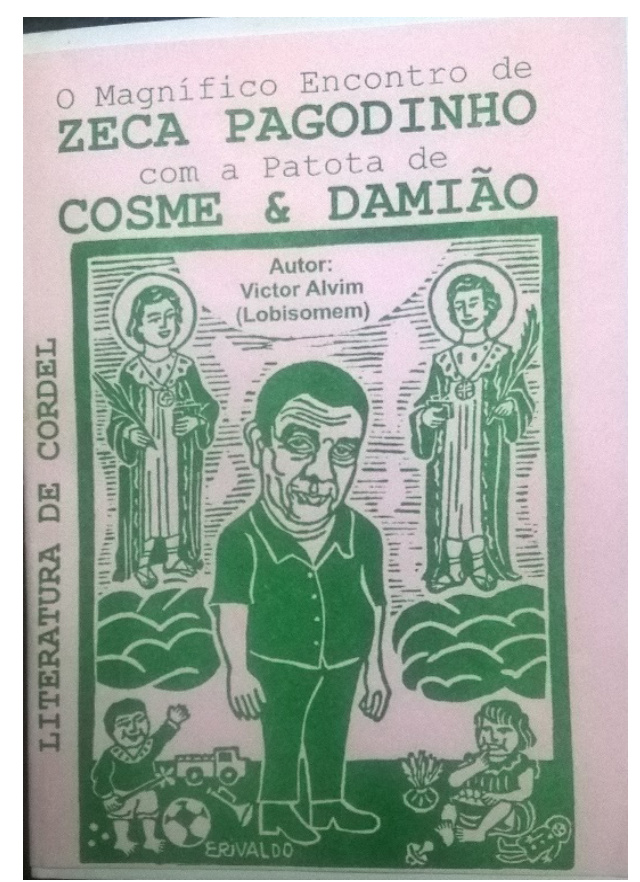

Imagem 6: Capa do cordel O magnífico encontro de Zeca Pagodinho com a patota de Cosme e Damião" de Victor Alvim, 2012 - Rio de Janeiro/RJ (Acervo pessoal)

Começando pelas crianças, o cordel "O magnífico encontro de Zeca Pagodinho com a patota de Cosme e Damião" de Victor Alvim, mais conhecido por Lobisomem, publicado no Rio de Janeiro em setembro de 2012, narra o sonho do autor, que viu o pagodeiro de Xerém/RJ se encontrar com várias entidades de Umbanda num dia vinte e sete de setembro, enquanto Zeca Pagodinho descansava em uma rede na sombra de uma Jaqueirão. Vale destacar que autor é capoeirista e umbandista, filho de Ogum, atuando como Ogã na Tenda Espírita Humildes de São Sebastião, fundada em 1948 no Bairro do Humaitá na cidade do Rio de Janeiro. Victor Alvim é um dos raros cordelistas umbandistas atuantes no país e também é membro da Academia Brasileira de Literatura de Cordel, ocupando a cadeira 27 que tem como patrono o cordelista Severino Milanês.

A capa do xilogravurista Erivaldo, mostra Zeca Pagodinho no centro 
olhando para o leitor sendo ladeado pelos Santos Cosme e Damião que estão sobre nuvens. Na parte de baixo da imagem estão duas crianças. No lado esquerdo um menino em pé com seus brinquedos: cata-vento (na mão), carrinho, corneta, bola de futebol e bolas de gude. Do lado direito uma menina sentada comendo doces de uma tigela que está em seu colo, e no chão uma boneca, uma chupeta e uma peteca.

A narrativa é bastante dinâmica, em sextilhas, mostrando as brincadeiras que o cantor participou com as crianças, todas elas tradicionais, como: amarelinha, bambolê, bola de gude, pipa, pião, futebol de botão, polícia e ladrão, futebol com bola de meia, peteca, entre outras. As brincadeiras eram tão intensas que fizeram o pagodeiro quase desmaiar, mas ao cair foi amparado pelas crianças, fazendo com que não se ferisse. Uma das características das entidades crianças na Umbanda, também conhecidas como erês ou ibejadas, é sempre pedir a benção aos que estão nas giras, e isso ocorre no cordel quando elas se dirigem ao cantor, beijam sua mão e dizem "a benção Titio Zeca" (p. $5)$.

E como podemos afirmar que são entidades crianças e não apenas crianças? Pelos nomes que o autor faz questão de citar, além de Noah: "Este aqui é o Doum/Este outro é o Crispim/Aquele é o Crispiniano/Gustavo e Joaquim/ Caboclinha, Crioulinha/Zezinho e Erê Curumim" (p. 4) e ainda "Mariazinha da Praia/Ritinha da Cachoeira/Joãozinho da Girafa/Pedrinho da Atiradeira/Zé Banana, Isabelinha/Juremita Choradeira" (p. 5). Todas estas são conhecidas crianças que incorporam em médiuns pelos terreiros de Umbanda no Brasil.

Não bastando a presença destas crianças espirituais, Zeca Pagodinho também recebe a visita dos Santos Cosme e Damião, que se apresentam também como protetores do cantor (ele é filho de Ogum). Depois de conversas e de orações, os santos se despendem juntamente com as crianças e o autor desperta de seu sonho.

Neste cordel percebe-se o envolvimento do autor com a religião umbandista. Os conceitos e características das entidades aparecem muito claramente descritas e eficientemente demostradas. É alguém de dentro da Umbanda escrevendo sobre suas entidades, caso raro, visto que esmagadoramente os cordelistas mais conhecidos e produtivos vem de uma tradição católica, o que fez desta religião a mais divulgada nos folhetos ao longo destes mais de cento e vinte anos do cordel brasileiro. 


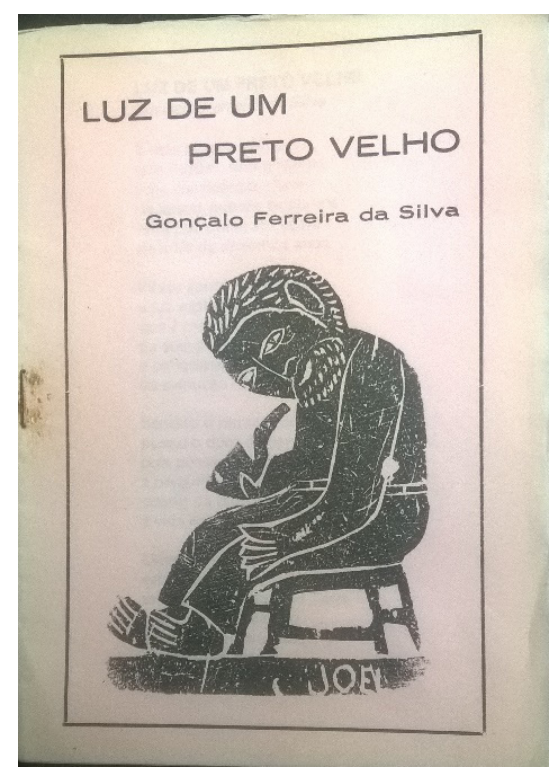

Imagem 7: Capa do cordel "Luz de um Preto Velho" de Gonçalo Ferreira da Silva, $\mathrm{s} / \mathrm{d}$ - Rio de Janeiro/RN (Acervo pessoal)

O cordel "Luz de Preto Velho" de Gonçalo Ferreira da Silva (s/d), apresenta aos leitores uma das mais importantes entidades espirituais da Umbanda. Já na capa com xilogravura de Joel, o Preto Velho aparece descalço, sentado em sem banquinho, segurando em uma das mãos o seu cachimbo e a outra está estendida sobre as pernas. A simplicidade da xilo e da imagem reproduzida já dialogam com os arquétipos da entidade, em sua postura humilde e resignada olhando para nós, leitores/consulentes.

Gonçalo Ferreira da Silva, nasceu em Ipu (CE) em 1937, atualmente é Presidente da Academia Brasileira de Literatura de Cordel, com sede no Rio de Janeiro e ocupa a cadeira de número 01 , tendo como patrono o poeta pai do cordel brasileiro, Leandro Gomes de Barros. O autor produziu mais de duzentos títulos, alguns inclusive traduzidos para outras línguas e seus folhetos versam sobre lendas, crenças, romances, política, biografias, fatos circunstanciais e históricos, cangaço, ciência e filosofia. Em "Luz de Preto velho" leva o leitor a compreender, mesmo que de forma sucinta, o universo que envolve a figura do Preto Velho que, segundo a crença umbandista, evoluiu através da dor, do sofrimento e do trabalho forçado. Ao mesmo tempo em que sofreu, resignou-se, e assim, dizem os seguidores da Umbanda, alcançou em sabedoria e generosidade o que outras entidades não conseguiram.

O próprio nome já os identifica. Os pretos velhos e as pretas velhas (os cacurucaios - ancião em quimbundo) são os homens ou mulheres africanos ou afro-brasileiros que ao viverem nas senzalas as mazelas da empresa escravocrata eram os conselheiros e curandeiros de seu grupo social. Neste caso a assimilação destes negros ao novo país foi determinante para sua sobrevivência, mesmo que 
em condições precárias. Negros que na África não possuíam contato, inclusive religioso, nos tumbeiros e no cativeiro forçado no Brasil, foram obrigados a se encontrar e se compreender.

A generosidade descrita como sendo uma das virtudes do Preto Velho é destacada no cordel de Gonçalo Ferreira da Silva, "é este poema pobre/Sem ilusões, sem enganos,/Uma confidência cheia/De lances nobres, humanos/Feita por um Preto Velho/ De mais de duzentos anos." (p. 1), e afirma que "pouca gente compreende/A luz espiritual/Que é manifestação/De energia vital/E conquista através/Da evolução moral" (p. 1). Mostra algumas características da entidade informando que "um Preto Velho de luz/Fala pouco e nunca erra/ Prega a paz reconfortante/Repele a sangrenta guerra/E presta contas de tudo/ Quando fala aqui na Terra" (p. 6).

Percebe-se um respeito afetuoso do autor para com a entidade de Umbanda. Suas qualidades são destacadas e reforça aquilo que vários autores já haviam explanado em pesquisas sobre a temática das religiões afro-brasileiras. Em muitos deles os Pretos Velhos são analisados juntamente aos Caboclos, entidades típicas da Umbanda e que de alguma forma possuem habilidades parecidas. Tanto o Preto Velho quanto o Caboclo, cumprem um papel bastante relevante nos rituais umbandistas. As suas gestualidades e posturas físicas nos trabalhos mediúnicos, são muito diferentes. $\mathrm{O}$ primeiro, normalmente curvado para frente, andar lento e pesado, fala baixo, usa alguns objetos (rosários ou terços, cruzes ou crucifixos, cachimbo ou cigarro de palha, bengala, entre outros). Já o segundo, apresenta-se ereto, anda e dança com agilidade, emite brados e fala mais alto, e pode ser visto utilizando alguns objetos como arco e flecha e cocares. Os dois tem em comum a especialidade de ajudar os consulentes nos casos de saúde. O Preto Velho ainda é procurado para dar conselhos e ajudar na resolução de conflitos, nunca acusando, mas sim buscando o entendimento entre as partes.

Este mesmo autor, em outro cordel utiliza sua poesia para desqualificar uma das mais importantes entidades de Umbanda, Exu. No o cordel "Exu - Cidade do diabo ou sucursal do inferno", o autor descreve os problemas enfrentados pela cidade pernambucana de Exu, como sabemos, cidade natal de Luiz Gonzaga, e as conturbações políticas e sociais do lugar. Em toda a descrição, a cidade é inundada por assassinos incorrigíveis, por ladrões impiedosos, por corrupção moral entre outras aterrorizantes condições em que a população é submetida, sem deixar de pontuar a histórica e longeva luta entre as famílias Sampaio e Saraiva contra os Alencar. O cordel foi escrito entre 1982 e 1988, já que informa que o prefeito de Exu na data da produção do folheto era Pedro Peixoto Alencar (p. 6). Segundo o poeta, é justamente por conta do nome da cidade que isto ocorre, visto que "Exu - palavra maldita/De macabro ritual/Botar na cidade o nome/Dum mensageiro do mal/Devia ser pelo menos/Inconstitucional" (p. 4). E continua afirmando "Exu - espírito do mal/ 
Do ódio e perversidade/Vive como provação/Da própria sociedade/Não é um nome indicado/Pra botar numa cidade" (p. 7). Todos os estereótipos fabricados sobre Exu estão presentes neste cordel. Existem duas versões para que Exu tenha este nome: a primeira fala de uma corruptela do nome da tribo Ançu da nação Cariri, e a outra é por conta de um tipo de abelha, denominada Inxu, muito comum na região. Ou seja, nada se refere ao Exu citado pelo cordelista.

Descrito como brincalhão, na literatura umbandista, mensageiro dos orixás e sensual, é, acima de tudo, o Orixá do movimento. A identificação dele com o diabo cristão remete-nos aos primeiros missionários que chegaram ao território africano e observaram sua imagem com falos e chifres (símbolos de fertilidade e poder, respectivamente, em muitas regiões da África sulsaarina) e de imediato não tiveram dúvida de defini-lo como o Diabo daquela região.

A Umbanda, de alguma forma, reforçou esta identificação nomeando as entidades que se apresentavam como exus com termos que ainda mais potencializavam esta aproximação: Exu Lúcifer, Exu Belzebu, Exu Sete Facadas, Exu Sete Covas, sendo estes alguns exemplos de uma lista de centenas de entidades que possuem nomes assustadores para aqueles que não pertencem ao universo umbandista, onde se sabe, são apenas nomes, nada mais, e que serviram por muito tempo para proteger os terreiros da perseguição policial, já que amedrontavam os agentes da repressão que preferiam não entrar nestes espaços que continham o "diabo" como um dos moradores. Controvérsias à parte, o Exu apresentado no cordel de Gonçalo Ferreira da Silva só reforça os preconceitos centenários relacionados a este Orixá da cultura religiosa africana e afro-brasileira e dos exus da Umbanda.

No cordel sobre Exu, Gonçalo Ferreira da Silva desqualifica um orixá do Candomblé, da Umbanda, da Jurema (entre outras), mas já em seu folheto sobre o Preto Velho utiliza vários adjetivos de positivação e reforça o respeito que os consulentes devotam à entidade, e consequentemente, demonstra as duas visões que ele possui sobre estas personagens do panteão religioso afrobrasileiro. Esta contradição é bastante evidente nos discursos dos kardecistas sobre a Umbanda e as religiões afro-brasileiras, e o autor, sendo kardecista, não difere deste universo de desqualificações em determinados momentos e de generosidades em outros. O campo religioso mediúnico historicamente esteve e está em constante conflito discursivo, disputando espaço para se afirmar, cada um com suas práticas, como os mais legítimos, puros e autênticos que os outros. 


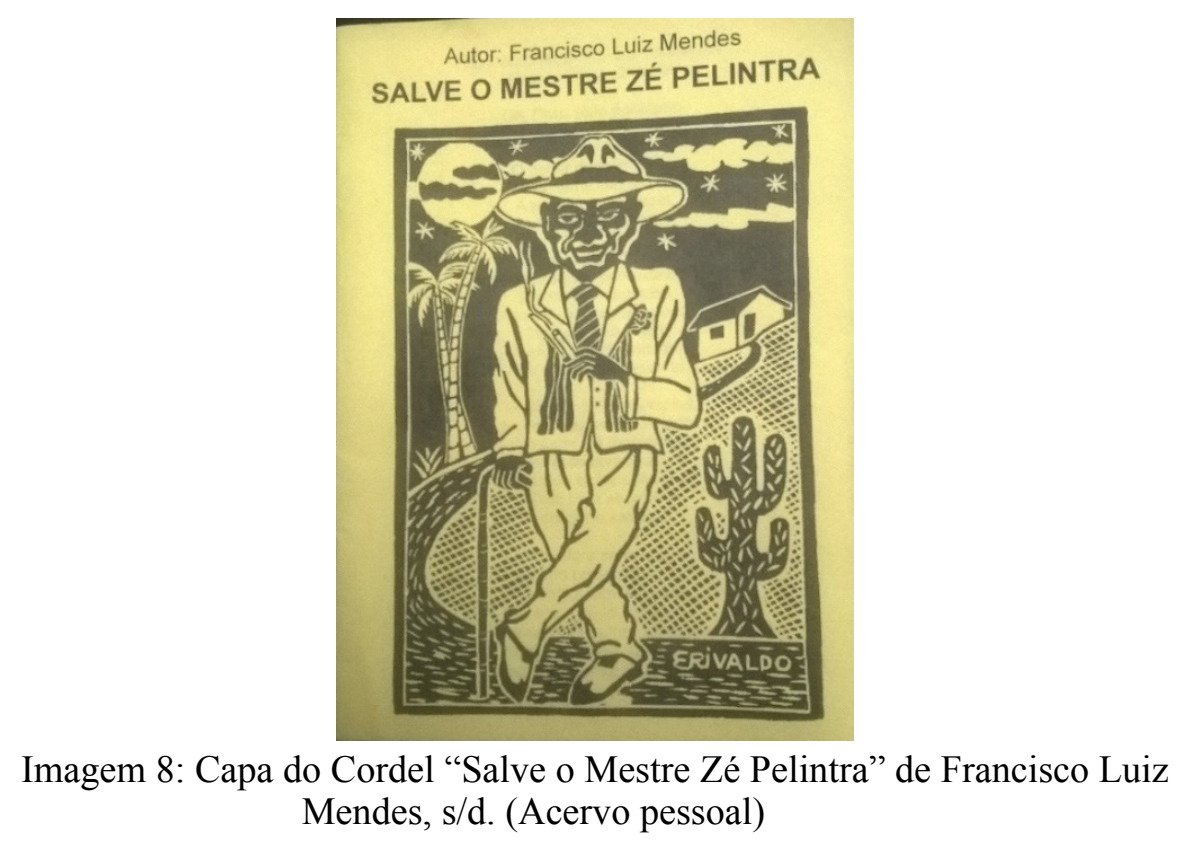

São poucos os cordéis que tratam de entidades de Umbanda especificamente, como é o caso do cordel "Salve o Mestre Zé Pelintra" de Francisco Luiz Mendes, também autor do cordel "Umbanda Cem anos de amor e caridade" e que novamente utiliza uma xilogravura de Erivaldo em seu folheto. Observa-se o protagonista no centro da imagem vestindo as roupas que the são atribuídas e que estão bem descritas na narrativa do cordel. Ele nos olha, nos observa. No canto direito embaixo está um cactos, mostrando sua origem sertaneja e nordestina. No canto esquerdo está um coqueiro, que aponta para a sua vida no litoral, sobretudo no Rio de Janeiro. O xilogravurista coloca a personagem num cenário noturno, já que o mesmo é descrito como boêmio e um ser que construiu sua vida nas noites cariocas da Lapa. Não vivia na rua, isso aparece no caminho que leva a uma humilde residência. A capa reforça as imagens descritas no corpo do texto e confirma o que se conta sobre Zé Pelintra nos terreiros espalhados pelo Brasil.

Conhecido no nordeste como Mestre Zé Pelintra, nascido próximo a Garanhuns/PE, migrou como tantos nordestinos para o Rio de Janeiro onde fez fama, amigos e inimigos. Ao morrer tornou-se uma entidade espiritual respeitada em terreiros de todo o Brasil, manifestando-se em terreiros de Catimbó-Jurema, na qualidade de Mestre e em terreiros de Umbanda, nas linha dos Exus, principalmente no sul e sudeste. Esta é uma entidade vinda da Jurema e apropriada pela Umbanda, fazendo com que Zé Pelintra se tornasse uma das entidades mais citadas e procuradas para dar conselhos e realizar mandingas.

$\mathrm{O}$ autor descreve seu modo de vestir, característico dos famosos malandros do início do século XX no Rio de Janeiro. O cordelista informa que 
ele se apresentava "vestido de terno branco/sua gravada grená/seu sapato bico fino/com seu chapéu Panamá/cravo rubro na lapela/essa era sua chancela/Co'a bengala maracá.” (p. 3). O diálogo entre capa e texto são bastante eficientes em mostrar o protagonista.

Ao longo do texto Zé Pelintra é adjetivado e suas características aparecem demarcando seu lugar na vida sertaneja (início de sua trajetória) e posteriormente na capital federal, o Rio de Janeiro. O autor não apresenta datas nem informações que pudessem temporalizar seu nascimento e morte, mas como já há bibliografia sobre esta personagem, mesmo que bastante heterogênea e pontual, é possível delimitar o nascimento de Zé Pelintra no final do século XIX. Em livro escrito por Mizael Vaz, em que o próprio Zé Pelintra conta sua história, ou seja, trata-se de uma obra psicografada, intitulada "Zé Pelintra: Sêo Dotô, Sêo Dotô! Bravo Sinhô!"”, o espírito afirma que seu nome de nascimento era José Porfírio Santiago, nascido em fazenda próxima a Garanhuns/PE, em 15 de fevereiro de 1886 e era filho de escravos. Toda sua história é contada em detalhes no livro, confirmando, no tocante as suas características como espírito de luz e que também aparecem no cordel.

Francisco Luiz Mendes cita diversas habilidades de Zé Pelintra no mundo da magia e da boemia, destacando-se como exímio jogador de cartas, mediador, mirongueiro, mas acima de tudo "soldado bendito do Nosso Senhor Jesus" (p. 5). A visão que o autor tem da personagem que biografa fica explicita na seguinte estrofe: "Zé Pelintra, o malandro,/ Zé Pelintra, o brasileiro./ Zé Pelintra, o nordestino,/ Zé Pelintra, o seresteiro./ Zé Pelintra, o protetor,/ Zé Pelintra, o sedutor,/ Zé Pelintra, o juremeiro.” (p. 5). Nesta passagem o autor coloca Zé em todas as suas dimensões, inclusive como juremeiro, o que reforça sua origem como aprendiz nos terreiros de Jurema do sertão nordestino, mas que leva estes conhecimentos ao migrar para o Rio de Janeiro e fez disso também seu ofício. Como homem da noite e dos caminhos se faz presente em giras de Umbanda e Jurema, trabalhando tanto na direita (mestre), como na esquerda (exu) o que faz dele uma das entidades mais híbridas e moventes do panteão das religiões afro-brasileiras. Zé Pelintra é respeitado pelo autor, que não poupa elogios a entidade e isso se consuma na última estrofe do cordel: "Finalizo o meu apreço/para esse mestre de luz,/O benfeitor Zé Pelintra,/Porta-voz da Santa Cruz./Boêmio da madrugada,/Senhor da encruzilhada,/Mensageiro de Jesus" (p. 8).

A Umbanda e o Cordel possuem quase a mesma idade, sendo que a primeira nasce em um grande centro urbano e se espalha para todo o Brasil e o cordel nasce no sertão nordestino e depois migrou para as grandes cidades brasileiras. Fazem o caminho inverso, mas nestes mais de cem anos buscaram seu reconhecimento. Visto por muitos como manifestações primitivas da cultura brasileira, desqualificas e desprestigiadas, nestes últimos anos vem ocupando seu lugar também nas pesquisas acadêmicas que desejam entender a Umbanda 
e o cordel como criações genuinamente brasileiras, uma como religião e a outra como gênero literário. Uma luta que não será fácil diante de uma elite intelectual ainda tacanha e excludente que se encastela em suas tradicionais convicções, como se a cultura e a própria tradição não fossem organicamente dinâmicas. O cordel se modificou ao longo das décadas, sobretudo nas temáticas e a Umbanda, não diferente, se ampliou a cada nova gira, a cada nova incorporação de entidades em seu panteão. O que era, nos dois casos, no final do século XIX e início do XX não o é mais no século XXI. O movimento é parte constituinte de suas Histórias.

Ainda é um namoro acanhado entre as temáticas umbandistas no cordel, mas já é o começo, principalmente quando a Umbanda e as religiões afro-brasileiras conseguem romper a barreira de um gênero literário que em sua origem e em sua trajetória trazem de forma marcante o catolicismo de seus autores impregnado em seus discursos poéticos. Continuarei acompanhando este namoro que pode virar casamento, rompimento ou permanecer apenas no namorico sem muito compromisso, o que também não é nada ruim.

\section{Notas de Fim}

1 ALBUQUERQUE JUNIOR, Durval Muniz. A feira dos mitos: a fabricação do folclore e da cultura popular (Nordeste 1920-1950). São Paulo: Intermeios, 2013.

2 CURRAN. Mark. Retrato do Brasil em Cordel. Cotia: Ateliê, 2011. p.72-73.

3 ROIPHE, Alberto. Forrobodó na linguagem do sertão: leitura verbovisual de folhetos de cordel. Rio de Janeiro: Lamparina; FAPERJ, 2013.

4 MEYER, Marlyse. Caminhos do imaginário no Brasil. São Paulo: EDUSP, 1993.

5 CUMINO, Alexandre. História da Umbanda: uma religião brasileira. São Paulo: Madras, 2011. p. 136-197.

6 VAZ, Mizael. Zé Pelintra: Sêo Dotô, Sêo Dotô! Bravo Sinhô!. São Paulo: Madras, 2013.

Artigo recebido em maio de 2017. Aceito em julho de 2017. 